\section{REFLEKSI HUKUM}

Jurnal Ilmu Hukum
p-ISSN 2541-4984 | e-ISSN 2541-5417

Volume 5 Nomor 1, Oktober 2020, Halaman 21-42

DOI: https://doi.org/10.24246/jrh.2020.v5.i1.p21-42

Open access at: http://ejournal.uksw.edu/refleksihukum

Penerbit: Fakultas Hukum Universitas Kristen Satya Wacana

\title{
KETAATAN NEGARA TERHADAP HUKUM PERDAGANGAN INTERNASIONAL
}

\author{
Muhammad Rafi Darajati \\ Fakultas Hukum Universitas Tanjungpura \\ Korespondensi: rafidarajati@untan.ac.id
}

Naskah diterima: 14 April 2020|Direvisi: 8 Mei 2020|Disetujui: 30 Oktober 2020

\begin{abstract}
Abstrak
Hukum perdagangan internasional merupakan bagian dari hukum internasional. Oleh karena itu, tentunya berbagai ketidaksempurnaan atau kelemahan yang dimiliki hukum internasional juga terdampak dalam bidang hukum perdagangan internasional. Artikel ini akan menjelaskan mengenai mengapa negara di dalam melakukan perdagangan internasional perlu untuk taat terhadap hukum perdagangan internasional. Artikel ini memberikan argumen bahwa yang menjadi alasan negara untuk taat kepada hukum perdagangan internasional, dikarenakan keyakinan bahwa ketaatan akan menguntungkan kepentingan negara itu sendiri. Alasan selanjutnya adalah terdapat prinsip yang fundamental dalam ruang lingkup perjanjian internasional yang merupakan sumber hukum dari hukum perdagangan internasional yaitu prinsip itikad baik. Suatu negara yang telah terikat di dalam perjanjian perdagangan internasional tersebut harus melaksanakan ketentuan perjanjian sesuai dengan isi, jiwa, maksud, dan tujuan perjanjian itu sendiri, menghormati hak-hak dan kewajiban-kewajiban dari masing-masing pihak.
\end{abstract}

Kata-kata Kunci: Negara; Ketaatan; Hukum Perdagangan Internasional.

\begin{abstract}
International trade law is part of international law. Therefore, various imperfections or weaknesses of international law are also affected in the field of international trade law. This article will explain why the state in conducting international trade needs to comply with international trade law. This article argues that the reason for the states to obey international trade law is due to the belief that obedience will benefit the interests of the country itself. The next reason is that there are fundamental principles within the scope of international treaties, which are the source of law from international trade law, namely the principle of good faith. A state that is bound in the international trade agreement shall implement the provisions of the treaty by contents, soul, purpose, and purpose of the treaty itself, respecting the rights and obligations of each party.
\end{abstract}

Keywords: State; Obedience; International Trade Law. 


\section{PENDAHULUAN}

Masyarakat internasional dalam bentuknya sekarang merupakan suatu tertib hukum koordinasi dari sejumlah negara yang masing-masing berdaulat. Dalam tata masyarakat internasional yang demikian, tidak terdapat suatu badan legislatif maupun kekuasaan kehakiman dan kepolisian yang dapat memaksakan berlakunya kehendak masyarakat internasional sebagaimana tercermin dalam kaidah hukumnya. ${ }^{1} \mathrm{Hal}$ ini berbeda dengan hukum di tingkat nasional yang memiliki lembaga-lembaga formal seperti badan legislatif, polisi, jaksa, kepala-kepala pemerintahan baik di pusat maupun daerah (eksekutif) serta pengadilan yang memiliki yurisdiksi wajib kepada penduduknya.

Ketiadaan lembaga-lembaga tersebut membuat hukum internasional mendapat pertanyaan apakah merupakan hukum yang sesungguhnya. Terlebih terdapat inkonsistensi penerapannya misalnya dalam invasi Kuwait oleh Irak pada tahun 1990an dimana terdapat begitu banyaknya respon dari masyarakat internasional baik secara hukum maupun milter. Akan tetapi tanggapan yang berbeda ketika untuk menyelesaikan konflik dan peperangan di Timur Tengah termasuk pelanggaran Hak Asasi Manusia (HAM) oleh pasukan perdamaian negara-negara dari khususnya Dewan Keamanan PBB. ${ }^{2}$

Terdapat sebuah kelemahan dari hukum internasional yang disampaikan oleh Greig yaitu kekurangan dalam hal lembaga legislatif sebagai lembaga pembuat hukum; ketidakhadiran pengadilan yang berwenang mengadili seluruh sengketa yang wajib ditangani; dan kelemahan dalam penjatuhan sanksi bagi negara-negara yang melanggar hukum, termasuk persoalan yang sangat jelas yaitu membedakan hukum internasional dan hukum nasional. ${ }^{3}$

Dalam praktiknya memang disadari bahwa hukum ternyata tidak selalu dapat diidentikan dengan penjamin kepastian hukum, penegak hakhak masyarakat, atau penjamin keadilan. Politik sering kali mengintervensi dalam pembuatan dan pelaksanaan hukum, termasuk di dalamnya adalah hukum internasional. 4

Salah satu cabang dari hukum internasional adalah hukum perdagangan internasional dimana luasnya bidang cakupan hukum perdagangan internasional membuat sulit untuk mengatakan bahwa tidak ada tumpang tindih dengan bidang-bidang lainnya. Misalnya dengan hukum ekonomi internasional, hukum transaksi bisnis internasional, hukum komersial internasional, dan lain-lain. ${ }^{5}$

Ketika membicarakan mengenai perekonomian dunia, maka sangat penting untuk memahami mengenai dasar dari perekonomian itu sendiri. Perekonomian tidak saja berkaitan dengan permasalahan untung, rugi, permintaan, dan pendapatan. Lebih dari itu adalah terhadap kerangka dari perdagangan internasional. Perdagangan merupakan sebuah kegiatan ekonomi yang sangat berpengaruh

$1 \quad$ Mochtar Kusumaatmadja dan Etty R. Agoes, Pengantar Hukum Internasional (Alumni 2003) 45.

2 Martin Dixon, Textbook on International Law (Blackstone Press 1990) 1.

3 D. W. Greig, International Law (Butterworth 1976) 4.

4 Sefriani, Peran Hukum Internasional Dalam Hubungan Internasional Kontemporer (RajaGrafiondo Persada 2016) 21.

$5 \quad$ Huala Adolf, Hukum Perdagangan Internasional (RajaGrafindo Persada 2006) 12. 
terhadap perekonomian masyarakat internasional.

Dewasa ini, banyak pelaku usaha menjalankan kegiatan perdagangan barang yang melewati batas-batas negaranya. Berdagang barang dengan pedagang asing merupakan kebutuhan dasar kaum pedagang untuk memperluas kesempatan memperoleh untung, di samping juga untuk mengalihkan produk dagang mereka yang tidak terserap di dalam pasar negara mereka sendiri. Dilihat dalam perspektif hubungan antar negara, perdagangan internasional menjadi suatu kebutuhan yang mendasar untuk kelangsungan dalam inter-pendensi ekonomi dunia. ${ }^{6}$

Perdagangan internasional yang didasarkan pada prinsip perdagangan bebas selalu menggunakan indikatorindikator ekonomi yang berorientasi kepada efisiensi, transparansi, dan persaingan secara terbuka antar pelaku usaha yang bersifat lintas negara. ${ }^{7}$

Liberalisasi perdagangan dan kerjasama ekonomi telah mengambil posisi dominan dalam agenda ekonomi global dan regional. Kerjasama ekonomi secara global maupun regional merupakan elemen penting dalam pelaksanaan kebijakan ekonomi serta merupakan salah satu bentuk peran aktif dari negara dalam pergaulan antar negara. Melalui kerjasama ekonomi baik secara regional maupun global, suatu negara dapat memanfaatkan kesempatan untuk menunjang dan melaksanakan pembangunan nasional yang pada akhirnya dapat meningkatkan kese-jahteraan rakyatnya.

Ada beberapa motif atau alasan mengapa negara atau masyarakat internasional melakukan transaksi dagang internasional, antara lain yaitu untuk mempermudah tersedianya bahan-bahan yang dibutuhkan yang belum bisa diproduksi sendiri oleh salah satu pihak yang terikat dalam transaksi, dan juga untuk mengatasi masalah kelangkaan bahan-bahan produksi yang dibutuhkan. Hal ini mengingat sumber daya alam merupakan materi yang ketersediaan-nya berbeda-beda di setiap tempat. 8

Oleh karena hukum perdagangan internasional merupa-kan cabang dari hukum internasional, tentunya berbagai ketidaksempurna-an atau kelemahan yang dimiliki oleh hukum internasional juga mencakup dalam bidang hukum perdagangan internasional. Salah satu yang menarik untuk dikaji adalah mengenai bagaimana seharusnya ketaatan masyarakat internasional atau negara terhadap hukum perdagangan internasional dan mengapa penting bagi masyarakat internasional atau suatu negara untuk menaati hukum perdagangan internasional. Ketaatan masyarakat internasional terhadap hukum perdagangan menjadi hal

krusial dikarenakan tujuan dari keberadaan hukum internasional itu sendiri adalah untuk mengatur hubungan-hubungan internasional agar terciptanya perdamaian dan ketertiban internasional.

6 Subianta Mandala, 'Harmonisasi Hukum Perdagangan Internasional: Sejarah, Latar Belakang dan Model Pendekatannya' (2016) 1 (1) Jurnal Bina Mulia Hukum 53, 54.

7 Ade Maman Suherman, 'Perdagangan Bebas (Free Trade Dalam Perspektif Keadilan Internasional' (2008) 5 (2) Indonesian Journal of International Law 251.

8 Hikmahanto Juwana, Hukum Internasional dalam Perspektif Indonesia sebagai Negara Berkembang (Yarsif Watampone 2010) 101. 
Hal tersebut menarik untuk dikaji karena di dalam dunia perdagangan internasional, suatu konflik sering terjadi. Terjadinya sebuah konflik sangat membutuhkan kehadiran hukum. Dalam pergaulan internasional negara, apabila menyangkut perdagangan pasti memiliki suatu kepentingan satu sama lain yang bisa berpotensi menghasilkan suatu perselisihan. Oleh karena itu, tulisan ini bertujuan untuk mengkaji alasan pentingnya bagi suatu negara untuk menaati keberadaaan hukum perdagangan internasional dalam menjalankan kegiatan perdagangan internasional.

\section{PEMBAHASAN}

\section{Integrasi Ekonomi}

Seiring perkembangan hukum perdagangan internasional, terjadi sebuah pembedaan terhadap konsep hukum dalam kaitannya dengan tradisi, norma, dan hierarki. Pembedaan konsep ini mempengaruhi bentuk jaringan ekonomi yang merupakan bagi integral dari globalisasi ekonomi. ${ }^{9}$ Integrasi ekonomi secara sederhana dapat diartikan sebagai integrasi dalam bidang ekonomi dengan tujuan utama untuk melakukan liberalisasi perdagangan antar negara di dalam skema integrasi ekonomi tersebut. Integrasi ekonomi dapat dilihat sebagai representasi dari keadaan dimana ekonomi nasional tidak lagi menjadi batas penghalang, melainkan bersatu dalam entitas yang lebih besar dan satu kesatuan.

Dalam modernisasi, masyarakat menjadi maju, baik dalam bidang pendidikan, teknologi, maupun dalam bidang perekonomian. Perubahan tersebut berdampak pada hubungan antar negara. Antara negara satu dan negara lainnya seolah-olah tidak mempunyai batas lagi. Hal itulah yang menandai terjadinya globalisasi. ${ }^{10}$ Globalisasi adalah sebuah istilah yang memiliki hubungan dengan peningkatan keterkaitan antar bangsa dan antar manusia di seluruh dunia melalui perdagangan, investasi, perjalanan, budaya dan bentuk-bentuk interaksi lain. Globalisasi ini cenderung menciptakan tatanan ekonomi dunia yang terpadu, menciptakan sistem ekologi yang tunggal, serta menciptakan jaringan komunikasi yang mencakup seluruh dunia. ${ }^{11}$ Globalisasi yang terjadi di seluruh dunia merupakan proses internasionalisasi komunikasi, perdagangan, dan organisasi ekonomi.

Perdagangan internasional ini penting bagi suatu negara karena secara realita perdagangan internasional sudah menjadi tulang punggung bagi negara untuk menjadi makmur, sejahtera, dan kuat. ${ }^{12}$ Negara dengan daya saing tinggi akan menjadi aktor dalam perdagangan internasional, sementara negara yang berdaya saing rendah hanya akan menjadi konsumen. ${ }^{13}$

Pembentukan pasar bersama berbasis regional akan semakin me-

9 Emmy Latifah, 'Eksistensi Prinsip-prinsip Keadilan dalam Sistem Hukum Perdagangan Internasional' (2015) 2 (1) Padjadjaran Jurnal Ilmu Hukum 64.

10 Dewi Anggraeni, 'Pencegahan Praktik Dumping dalam 'Asean China Free Trade Area' Berkaitan dengan Peraturan Pemerintah Nomor 34 Tahun 2011' (2017) 5 (1) Jurnal Cita Hukum 135, 137. William Twinning, Globalisation and Legal Theory (Butterworths 2000) 4.

Ibid., 2.

Muhammad Rafi Darajati, 'Pemberlakuan Ketentuan Regulatory Coherence dalam Trans Pacific Partnerhip Agreement Bagi Negara Pihak dalam Perspektif Indonesia' (2019) 4 (2) University of Bengkulu Law Journal 137. 
ngembangkan arus globalisasi tersebut, salah satunya adalah pembentukan Masyarakat Ekonomi ASEAN, dimana program integrasi tersebut merupakan reaksi terhadap tantangan globalisasi. Dalam hal ini, globalisasi mengimplikasikan pertumbuhan pasar dan transaksi keuangan.

Dasar pemikiran penerapan globalisasi perdagangan ini dilandasi oleh konsep Adam Smith, bahwa negara akan tetap memperoleh keuntungan apabila memusatkan kegiatan dengan biaya lebih rendah daripada kegiatan alternatif lainnya di negara itu, walaupun negara mitra dagangnya mempunyai keunggulan di semua bidang. Sebaliknya, untuk memenuhi kebutuhan internal akan produk lainnya, negara yang bersangkutan dapat mengimpor. ${ }^{14}$

Dari pemikiran tersebut terlihat bahwa globalisasi sangat erat kaitannya dengan ekonomi. Dapat dilihat bahwa perkembangan ekonomi dunia saat ini mengarah pada meningkatnya keterbukaan hubungan ekonomi antar bangsa. Globalisasi ekonomi adalah kehidupan ekonomi global yang tidak mengenal batas-batas wilayah antara negara yang satu dengan negara lainnya. Percepatan proses globalisasi dalam dua dekade terakhir ini secara fundamental telah mengubah struktur dan pola hubungan perdagangan dan keuangan internasional. Hal ini menjadi fenomena penting sekaligus. Merupakan suatu era baru yang ditandai dengan adanya pertumbuhan perdagangan internasional yang tinggi. ${ }^{15}$

Proses globalisasi yang menjadi gejala yang harus dihadapi oleh nega- ra-negara dan bangsa-bangsa di seluruh wilayah dunia, terjadi karena dorongan perkembangan kapitalisme internasional dan di dalamnya juga menyertakan transformasi budaya dan struktur sosial bagi masyarakat yang semula merupakan masyarakat non kapitalis, dan bahkan masyarakat yang masuk dalam kategori preindustrial societies. Proses globalisasi pada aspek ekonomi dapat dicermati dari perjanjian perdagangan internasional yang berlaku pada level hubungan antar negara, sistem hukum nasional, maupun kerangka relasi individual. Pada saat yang sama juga ditandai dengan meningkat-pesatnya volume perdagangan internasional serta meningkatnya interdependensi ekonomi di antara negara-negara. ${ }^{16}$

Adapun globalisasi ekonomi ini memacu terjadinya perdagangan internasional. Oleh karena itu, banyak kalangan yang menyebutkan bahwa globalisasi ini merupakan sebuah fenomena yang sangat menjanjikan. Perluasan perdagangan internasional dapat dikatakan menawarkan sejumlah peluang, termasuk kepada yang tingkat perekonomiannya menengah ke bawah untuk memperbaiki kualitas ekonomi mereka.

Demi terciptanya keteraturan dan kepastian dalam mengakomodasi berbagai kepentingan pelaku bisnis, hukum ekonomi dan bisnis akan menjadi kebutuhan yang tidak terelakan sebagai pedoman fundamental. Berbagai studi tentang hubungan hukum dan pembangunan ekonomi menunjukkan bahwa pembangunan

\footnotetext{
14 Jamilus, 'Analisis Fungsi Dan Manfaat WTO Bagi Negara Berkembang (Khususnya Indonesia)' (2017) 11 (2) Jurnal Ilmiah Kebijakan Hukum 200.

$15 \quad$ Anggraeni (n 10) 139.

16 Sigit Riyanto, 'Kedaulatan Negara Dalam Kerangka Hukum Internasional Kontemporer' (2012) 1
} (3) Yustisia 1, 5. 
ekonomi tidak akan berhasil tanpa pembaruan hukum. ${ }^{17}$

Perdagangan internasional merupakan aktivitas pertukaran barang, jasa, ataupun modal yang melintasi batas negara. Biasanya aktivitas ini disebut sebagai kegiatan ekspor, yakni menjual dan mengirim barang/jasa keluar negeri, dan impor, yaitu membeli dan menerima kiriman barang/ jasa dari luar negeri. ${ }^{18}$

Keberadaan hukum sangat penting di era globalisasi yang ditandai dengan globalisasi ekonomi yang kapitalis. Hal ini juga untuk melindungi aset-aset dari suatu negara, dan memberikan keadilan bagi negara lainnya yang berinvestasi atau melakukan kerjasama dengan negara lain.

Sedangkan hukum perdagangan internasional tertuju pada hukum yang mengatur kebijakan-kebijakan yang dibuat oleh berbagai pemerintah di bidang perdagangan. Pemerintah bertindak sebagai regulator yang memiliki kewenangan untuk membuat kebijakan yang tidak saja bagi pelaku usaha yang melakukan kegiatan di wilayahnya, tetapi juga kewenangan untuk membuat kebijakan atas barang dan jasa asal negara lain yang akan masuk ke negaranya. ${ }^{19}$ Saling bersinggungan di bidang ekonomi tentu memerlukan sebuah harmonisasi hukum lintas negara sebagai aturan main dan kesepakatan bersama untuk perdagangan internasional.
Ekonomi suatu negara tidak mungkin tumbuh bila negara hanya bergantung pada pasar dalam negeri. Terlebih ekonomi suatu negara tidak akan berkelanjutan jika hanya bergantung pada penjualan sumber daya alam dikarenakan sumber daya alam dapat habis. Bagi negara yang memiliki kekuatan ekonomi, mereka akan mendorong pelaku usahanya untuk memperluas dan melakukan ekspansi pasarnya ke luar negeri. Melakukan ekspansi ke luar negeri berarti menciptakan permintaan. Hal tersebut akan membuka lapangan kerja, lapangan kerja penting karena setiap pemerintahan mempunyai tanggung jawab memberikan kesejahteraan bagi rakyatnya. Di samping membuka lapangan kerja, ekspansi pelaku usaha ke luar negeri akan memberikan kontribusi devisa kepada negara dan sebagai penggerak perekonomian negara. Oleh karena-nya, merupakan hal yang wajar jika negara akan memfasilitasi agar pelaku usahanya dapat masuk ke pasar luar negeri. ${ }^{20}$

Namun, untuk menembus pasar di luar negeri, bahkan menjadikan sebuah negara sebagai tempat produksi, pelaku usaha kerap menemukan kendala. Kendala terse-but berupa berbagai hambatan perdagangan, baik tarif maupun non tarif yang diberlakukan oleh negara tujuan. Dalam hal inilah yang menjadi penting bagi suatu perjanjian perdagangan bebas untuk menghi-langkan berbagai

Erman Rajagukguk, 'Menjaga Persatuan Bangsa, Memulihkan Ekonomi, dan Memperluas Kesejahteraan Sosial' (2003) 22 (5) Jurnal Hukum Bisnis 22.

18 Endra Wijaya, Kikin Nopiandri, dan Habiburrokhman, 'Dinamika Upaya Melakukan Sinergi Antara Hukum Perdagangan Internasional Dan Hukum Lingkungan' (2017) 6 (3) Jurnal Hukum dan Peradilan 481.

19 Satria Unggul Wicaksaa Prakasa, 'Perdagangan Internasional Dan Ham: Relasinya Dengan Suistainable Development' (2018) 9 (1) Jurnal Hukum Novelty 36.

20 Hikmahanto Juwana, 'Masyarakat Ekonomi ASEAN dan Tantangannya bagi Indonesia: Dalam Perspektif Hukum Perdagangan Internasional' (Dies Natalis Universitas Indonesia, Depok, Februari 2016) 3. 
hambatan tersebut. Perjanjian ini bisa bersifat bilateral, regional, dan multilateral. Tujuan dari perjanjian ini adalah agar menjadikan perdagangan antar negara sama seperti perdagangan antar wilayah di satu negara yang tidak mengenal berbagai hambatan. Semakin hilang-nya hambatan dalam perdagangan internasional tersebutlah yang dapat menciptakan suatu integrasi ekonomi dalam masyarakat internasional.

\section{Ketaatan Terhadap Hukum Internasional}

Hukum, menurut Mochtar Kusumaatmadja dipahami tidak saja sebagai keseluruhan asas dan kaidah untuk mengatur kehidupan manusia dalam masyarakat, akan tetapi juga termasuk lembaga dan proses untuk mewujudkan berlakunya kaidah itu dalam kenyataan. Hal tersebut juga berlaku di dalam tingkatan internasional. Setiap kehidupan bermasyarakat membutuhkan suatu tatanan perilaku yang diakui sebagai kuat dan mengikat. ${ }^{21}$

Pada umumnya, hukum internasional diartikan sebagai himpunan dari peraturan-peraturan dan ketentuan-ketentuan yang mengikat serta mengatur hubungan antara negaranegara dan subjek-subjek hukum lainnya dalam kehidupan masyarakat internasio-nal. ${ }^{22}$ Hukum internasional secara umum dibentuk dengan maksud untuk menjadi pedoman negaranegara dalam melakukan aktivitas internasional, serta membatasi kedaulatan tiap-tiap negara.

Di dalam tubuh hukum internasional, meliputi juga: 23

1. Kaidah-kaidah hukum yang berkaitan dengan pelaksanaan fungsi lembaga-lembaga dan organisasi-organisasi internasional serta hubungannya antara negaranegara dan individu-individu.

2. Kaidah-kaidah hukum yang mengatur kepentingan individuindividu dan kesatuan bukan negara, sepanjang hak-hak dan kewajiban dari individu-individu dan kesatuan bukan negara tersebut hasil kesepakatan anta negara yang dituangkan dalam bentuk perjanjian.

Hukum internasional publik memiliki sistem negara sendiri, dengan keunikan dalam penegakan peraturannya. Oleh karena hukum internasional juga terpisah dari suatu hukum negara municipal law, tidak sedikit pandangan yang mengatakan hukum internasional diragukan sebagai sesuatu yang bukan peraturan hukum. Padahal, jika diselami secara lebih mendalam, sebenarnya hukum itu tidak saja sekedar menyangkut mekanisme pembuatan, pelaksanaan, maupun pemaksaannya, melainkan jauh lebih luas dan dalam. Di dalam hukum, terkandung nilai-nilai, rasa keadilan, dan kesadaran hukum yang terdapat di dalam hati sanubari setiap individu maupun masyarakat. ${ }^{24}$

Secara umum, norma-norma hukum internasional diakui sebagai tra-

21 Melda Kamil Ariadno, 'Kedudukan Hukum Internasional dalam Sistem Hukum Nasional' (2008) 5 (3) Indonesian Journal of International Law 505.

22 Boer Mauna, Hukum Internasional Pengertian Peranan dan Fungsi dalam Era Dinamika Global (Alumni 2013) 1.

23 Harry Purwanto, 'Keberadaan Asas Pacta Sunt Servanda dalam Perjanjian Internasional' (2009) 21 (1) Mimbar Hukum 155.

24 I Wayan Parthiana, Pengantar Hukum Internasional (Mandar Maju 2003) 18. 
disi hukum yang tidak dapat ditolak keberadaannya karena kenyataan era trans nasionalisme dan global village pada saat ini dimana suatu negara tidak mungkin mengingkari pengaruh dan hubungan saling ketergantungannya dengan negara lain. Sebagai sebuah hukum, hukum internasional memiliki empat sumber hukum yang terdapat di dalam Statute of the International Court of Justice, tepatnya di dalam Pasal 38 ayat (1) yakni: perjanjian internasional, hukum kebiasaan internasional, prinsip hukum umum, yurisprudensi dan doktrin.

Eksistensi suatu hukum sebenarnya lebih ditentukan oleh sikap dan pandangan serta kesadaran hukum dan masyarakat. Apabila masyarakat merasakan, menerima, dan menaati suatu kaidah hukum, disebabkan karena memang sesuai dengan kesadaran hukum dan rasa keadilan dari masyarakat, terlepas dari ada atau tidak adanya lembaga ataupun aparat penegak hukumnya, maka kaidah tersebut sudah dapat dipandang sebagai kaidah hukum. Memang, adanya badan legislatif, badan kehakiman, dan polisi merupakan ciri yang jelas dari suatu sistem hukum positif yang efektif, tetapi ini tidak berarti bahwa tanpa lembaga-lembaga ini tidak terdapat hukum. Hukum internasional itu mengikat bagi negara, bukan karena kehendak mereka satu per satu untuk terikat, melainkan karena adanya suatu kehendak bersama, yang lebih tinggi dari kehendak masing-masing negara untuk tunduk pada hukum internasional. ${ }^{25}$

Oppenheim mengemukakan bahwa hukum internasional adalah hu- kum yang sesungguhnya. Ada tiga syarat yang harus dipenuhi untuk dikatakan sebagai hukum menurut Oppenheim. Ketiga syarat yang dimaksud adalah adanya aturan hukum, adanya masyarakat, serta adanya jaminan pelaksanaan dari luar (external power) atas aturan tersebut. Syarat yang pertama tentunya sudah banyak ditemui yakni salah satu sumber hukum dari hukum internasional adalah perjanjian internasional, dan sudah banyak perjanjian internasional yang telah ditaati oleh negara, di dalam perdagangan internasional misalnya ada ASEAN Free Trade Area, perjanjian World Trade Organisation, dan lain sebagainya.

Untuk syarat yang kedua yakni adanya masyarakat internasional juga terpenuhi menurut Oppenheim. Masyarakat internasional tersebut adalah negara-negara dalam lingkup bilateral, trilateral, regional maupun universal. Adapun syarat ketiga adanya jaminan pelaksanaan juga terpenuhi menurut Oppenheim. Jaminan pelaksanaan dapat berupa sanksi yang datang dari negara lain, organisasi internasional ataupun pengadilan internasional. Sanksi tersebut dapat berwujud tuntutan permintaan maaf (satisfaction), ganti rugi (compensation), serta pemulihan keadaan pada kondisi semula (repartition). Disamping itu ada pula sanksi yang wujudnya kekerasan seperti pemutusan hubungan diplomatik, embargo, pembalasan, sampai ke perang. ${ }^{26}$

Andrew T. Guzman menjelaskan bahwa hukum internasional dapat mempengaruhi perilaku negara di dalam bermasyarakat. Melalui teori

\footnotetext{
$25 \quad$ Kusumaatmadja (n 1) 46.

26 Sefriani, 'Ketaatan Masyarakat Internasional terhadap Hukum Internasional dalam Perspektif Filsafat Hukum' (2011) 18 (3) Jurnal Hukum Ius Quia Iustum 400.
} 
the Three R's of Compliance, Guzman mengemukakan bahwa ada tiga " $R$ " yang dapat mempengaruhi perilaku ketaatan atau ketidaktaatan negara terhadap hukum internasional. Tiga " $\mathrm{R}$ " tersebut adalah reputation, reciprocity, dan retaliation. 27

Berdasarkan teori ini pelanggaran hukum internasional yang dilakukan oleh suatu negara akan mengakibatkan reputasinya buruk di mata masyarakat internasional. Reputasi ini berupa penilaian dari masyarakat internasional tentang perilaku negara saat ini dan prediksi ketaatan di masa yang akan datang berdasarkan perilaku buruknya di masa sekarang. Reputasi buruk yang didapat suatu negara akan berpengaruh pada hilangnya kesempatan-kesempatan untuk mendapatkan keuntungan yang lebih besar di masa yang akan datang seperti kerja sama perdagangan. masuknya investasi asing, bantuan asing, dan lain sebagainya.

Selain mendapatkan reputasi yang buruk, ketidaktaatan suatu negara pada kewajiban internasional akan mendatangkan sikap atau tindakan timbal balik dan atau pembalasan dari negara lain yang tentunya berpotensi untuk memperburuk hubungan dengan negara lain. Menjadi buruknya hubungan dengan negara lain tentunya akan merugikan negara itu sendiri karena pada dasarnya walaupun negara tersebut negara maju tidak ada suatu negara yang dapat bertahan untuk hidup sendiri tanpa melakukan hubungan internasional dengan negara lain.

Pada umumnya suatu negara di dalam melakukan hubungan internasional bertujuan untuk menyejah- terakan warganya. Pengu-cilan diri dari masyarakat internasional tentunya bukan merupakan suatu pilihan yang bijak karena apabila suatu negara terasing atau terputus hubungan dengan negara lain maka yang akan menderita adalah rakyatnya sendiri. Oleh karena itu di dalam melakukan interaksi atau hubungan dengan negara lain harus sesuai aturan hukum internasional dan hukum internasional akan berfungsi maksimal jika negara-negara patuh atau taat terhadap hukum tersebut. Apabila negara-negara yang melakukan kegiatan perdagangan internasional patuh terhadap hukum perdagangan internasional maka masyarakat internasional akan merasakan ketertiban, keteraturan, keadilan, dan keamanan dalam pelaksanaan hubungan internasional.

Kalaupun hukum internasional dewasa ini diragukan manfaatnya bahkan diingkari keberadaannya, maka yang harus dilakukan bukan membuang hukum internasional, tetapi mencari dan memperbaiki kelemahan-kelemahan yang ada dalam hukum internasional itu sendiri seperti struktur hukumnya, lembaga, maupun budaya hukumnya. Suatu hal yang cukup menggembirakan adalah keberadaan dan pengaruh hukum internasional dalam keseluruhan sistem hubungan internasional tetaplah diakui. Hukum internasional secara langsung telah memberikan pengaruh yang cukup signifikan dalam keberlangsungan hubungan internasional sampai pada hal-hal yang tampaknya tidak signifikan. Hukum internasional secara tidak langsung juga berusaha untuk mempengaruhi jalannya hubu-

27 Andrew T. Guzman, How International Law Works A Rational Choice Theory (Oxford University Press 2008) 33. 
ngan internasional. Beberapa bukti untuk memperkuat bahwa hukum internasional dalam kehidupan sehari-hari dari masyarakat internasional telah diterima dan ditaati sebagai hukum dalam pengertian yang sebenarnya, yaitu:28

1. Organ-organ pemerintah negara, khususnya yang dalam tugas dan kewenangannya berhubungan dengan masalah luar negeri atau internasional, tetap menghormati prinsip-prinsip dan kaidah hukum internasional dalam hubungan-hubungan antara sesamanya. Mereka masing-masing mewakili negara-nya, bertindak untuk dan atas nama negaranya. Ini berarti, bahwa negara-negara melalui organ pemerintahnya menghormati hukum internasional. Misalnya ketika mereka telah menyepakati suatu perjanjian internasional, mereka tetap menaatinya atau dengan kata lain tidak mau melanggarnya, meskipun kesempatan untuk melanggarnya itu selalu ada.

2. Persengketaan antara subjeksubjek hukum internasional khususnya yang mengandung aspek-aspek hukum. Meskipun tidak selalu, mereka menyelesaikan dengan cara damai melalui berbagai alternatif penyelesaian sengketa. Semua ini merupakan cara-cara penyelesaian sengketa yang diakui legalitasnya oleh hukum internasional. Demikian pula hasil penyelesaiannya, baik berupa perjanjian-perjanjian perdamaian maupun keputusan badan peradilan internasional, ditaati oleh para pihak yang ber- sengketa. Meskipun kadang-kadang ada pihak yang melanggarnya, namun pelang-garan ini tidak menghilangkan sifat dan hakikatnya sebagai hukum internasional.

3. Pelanggaran-pelanggaran atas kaidah hukum internasional ataupun terjadinya konflik internasional sebenarnya hanya-lah sebagian kecil saja jika dibandingkan dengan perilaku atau praktik dari masyarakat internasional yang pada hakikatnya merupakan tindakan mentaati dan menghormati hukum internasional. Akan tetapi, pelanggaran atas hukum internasional bukan alasan untuk mengatakan bahwa hukum internasional itu sama sekali tidak ada. Masih jauh lebih banyak masyarakat internasional yang menaati hukum internasional dibanding dengan yang melanggarnya.

4. Kaidah hukum internasional dalam kenyataannya ternyata banyak diterima dan diadopsi menjadi bagian dari hukum nasional negara-negara. Ini berarti bahwa negara-negara sebelumnya sudah menerima eksistensi hukum internasional sebagai bidang hukum yang berdiri sendiri yang dengan melalui cara atau prosedur tertentu dapat diadopsi menjadi bagian dari hukum nasionalnya. Bahkan dalam beberapa hal, hukum internasional harus diperhitungkan dan diperhatikan oleh negara-negara dalam menyusun peraturan perundang -undangan nasionalnya menge-nai suatu masalah tertentu 
5. Bahkan negara-negara yang sedang berperang pun juga masih tetap menaati prinsip-prinsip dan kaidah-kaidah hukum perang internasional atau yang sekarang dikenal dengan nama hukum humaniter. Demikian pula setelah berakhirnya perang, misalnya setelah tercapainya perdamaian, mereka masih tetap membutuhkan peranan hukum internasional untuk mengatur perdamaian misalnya dengan merumuskan hasil perdamaian itu dalam bentuk perjanjian perdamaian yang sudah jelas merupakan hukum internasional yang mengikat mereka.

Ketidaksempurnaan dari hukum internasional membuat masyarakat internasional melakukan upaya untuk mengefektifkan penegakan hukum internasional, cara yang dapat ditempuh adalah apabila negara-negara tersedia untuk mengurangi kedaulatannya. Tanpa kesediaan mengurangi kedaulatan, mustahil hukum internasional bisa efektif. Kedaulatan saat ini bukan merupakan alasan bagi negara untuk menutup diri dari proses interaksi perdagangan internasional dengan negara lainnya. Kapasitas untuk menjalin hubungan dan berinteraksi dengan pihak eksternal justru memperkuat makna kedaulatan negara yang bersang-kutan.

Namun patut pula ditegaskan bahwa kesediaan negara-negara mengurangi kedaulatannya adalah juga berdasarkan pada pertimbangan faktor politik. Tegasnya dengan kesediaan mengurangi kedaulatan-nya, sejauh manakah kepentingan negara-negara itu akan terakomo-dasikan secara politik. Jadi, tetap saja faktor politik yang berperan secara dominan.

Hukum internasional bukanlah sesuatu yang netral dan dapat berpihak, terkadang berpihak pada mereka yang kuat secara finansial. Namun pada masa tertentu hukum internasional dapat berpihak pada mereka yang memiliki mayoritas suara. Ketidaknetralan hukum internasional dikarenakan hukum ini adalah buatan manusia. Sehingga hukum internasional memiliki fungsi lain yaitu sebagai instrumen yang digunakan oleh pemerintahan suatu negara untuk mencapai tujuan nasionalnya. Suatu negara akan menggunakan berbagai instrumen politik, seperti kepentingan ekonomi, ketergantungan dalam masalah pertahanan, dan hukum internasional untuk mengenyampingkan halangan kedaulatan negara lain dalam mencapai kepentingan nasionalnya. Sebagai instrumen politik, pemanfaatan hukum internasional kerap mewarnai hubungan antar negara, terutama yang dilakukan oleh negara maju terhadap negara berkembang. Pemanfaatan hukum internasional sebagai alat politik digantungkan pada perjanjian internasional. ${ }^{29}$

Meskipun demikian, dengan usaha-usaha untuk mengefektifkan hukum internasional, meskipun kelemahan-kelemahannya masih tetap ada, dalam beberapa hal sudah menunjukkan hasil yang patut diperhitungkan. Adapun beberapa usaha

29 Hikmahanto Juwana, 'Memaksimalkan Peran Politik Luar Negeri Bebas Aktif: Perspektif Hukum Internasional' dalam Idris, dkk (ed)., Peran Hukum Dalam Pembangunan Indonesia Kenyataan, Harapan, dan Tantangan (Rosda Rosdakarya 2013) 632. 
yang telah dilakukan adalah sebagai berikut: 30

1. Melalui pembentukan organisasi internasional yang disertai dengan organ-organ serta peraturan internalnya yang bersifat mengikat sebagai hukum internasional terhadap negara-negara anggotanya dan diterapkan dalam hubungan antar mereka maupun dalam kerangka organisasi interna-sional itu sendiri. Namun, setiap organisasi internasional yang ada di dunia ini memang tidak sama tingkat keefektifannya. Ada yang dengan efektif dapat menerapkan hukum internasional, ada pula yang kurang efektif, bahkan tidak jarang yang tidak efektif sama sekali. Berbagai faktor dapat menjadi penyebab dari perbedaan-perbedaan ini.

2. Melengkapi perjanjian internasional multilateral dengan orangorgan pelaksanaannya. Suatu perjanjian internasional pada hakikatnya adalah merupakan hasil kata sepakat antara negaranegara yang terikat pada perjanjian itu. Praktik negara-negara menunjukkan, bahwa mengandalkan kesadaran hukum negara-negara untuk menaati perjanjian internasional ternyata tidak efektif. Agar suatu perjanjian internasional bisa lebih efektif dalam penerapannya terhadap negara-negara yang terikat, perjanjian internasional itu sendiri dilengkapi dengan organ pelaksanaannya.

3. Mencantumkan klausula penyelesaian sengketa dalam perjanjianperjanjian internasio-nal, baik perjanjian internasional bilateral maupun multilateral. Dengan mencantumkan klausu-la ini, jika terjadi persengketaan antara negara-negara yang terikat pada perjanjian interna-sional yang bersangkutan, para pihak yang bersengketa dapat menempuh jalur penyelesaiannya sesuai dengan klausula tersebut. Apapun hasil akhir dari penyelesaiannya, diharapkan akan ditaati oleh para pihak yang bersangkutan.

Dengan melalui langkah-langkah seperti di atas, ternyata hukum internasional relatif bisa lebih efektif meskipun tidak secara keseluruhannya. Namun upaya seperti ini bukan cara yang terkonsepsikan secara sistematis, melainkan tumbuh dan berkembang dalam praktik hubungan internasional secara kasuistis.

Kesediaan suatu negara masuk menjadi anggota suatu organisasi internasional, maupun kesediaan suatu negara untuk menyatakan persetujuannya terikat dan tunduk pada suatu perjanjian internasional, baik perjanjian itu disertai dengan organ pelaksana maupun klausula penyelesaian sengketa atau tidak, pada hakikatnya adalah manifestasi dan kesediaan mereka untuk mengurangi substansi kedaulatannya. Akan tetapi, jika pada suatu waktu negara yang bersangkutan memandang bahwa keterikatannya itu merugikan kepentingan nasionalnya, negara itupun tidak segan-segan menolak untuk menaati perjanjian ataupun keputusan dari organisasi internasional ataupun organ-organ pelaksana perjanjian itu ataupun hasil atau kepu- 
tusan dari badan penyelesaian sengketa yang bersang-kutan. ${ }^{31}$

Peranan hukum internasional mencakup seluruh aspek perbuatan dan hubungan antar negara, seperti pemanfaatan darat, laut, udara; dalam aspek non hukum publik, mengatur telekomunikasi internasional, pelayanan perbatasan negara, pengangkutan barang dan orang melalui kapal laut dan udara, dan juga mengatur tentang transaksi pengiriman uang, karena itu hukum internasional berkaitan dengan hukum perdagangan.

Hukum internasional sangat penting secara intrinsik dengan daya ikat praktik diplomasi, politik internasional dan tindakan hubungan luar negeri. Karena itu, jika hukum internasional telah diakui perannya dalam masyarakat internasional, tidak dinafikan lagi efektivitas hukum internasional dalam penegakannya. Timbulnya keraguan apakah hukum internasional itu betul-betul bekerja secara efektif telah ditinggalkan oleh banyak pihak. Beberapa alasan signifikan yaitu sebagai berikut: tidak ada keraguan bahwa hukum internasional telah berfungsi efektif didasarkan pada suatu keniscayaan dan kepentingan negara-negara.

Begitu besar dan tangguhnya hubungan antar negara, maka hukum internasional dibutuhkan untuk menjamin adanya suatu stabilitas dan tatanan tertib internasional, sebab setiap kepentingan negara-negara hanya mungkin berlangsung secara tertib dan teratur jika negara-negara dibatasi oleh hukum internasional.

Secara psikologis, aturan-aturan hukum internasional sebagai suatu sistem yang menjadi alasan mengapa negara-negara mematuhinya, begitu negara melanggar hukum internasional maka penanganannya tidak jauh berbeda dengan individu yang melanggar hukum nasional. Maka upaya untuk melakukan penegakan-nya adalah masyarakat internasional ambil bagian untuk menegakkannya; para praktisi politik, menggunakan hukum internasional dalam seluruh aspek kerjasama internasional dan penyelesaian sengketa internasional.

Sebuah bukti nyata yang dapat dijadikan contoh untuk menunjukkan dapat ditegakkannya hukum internasional adalah penjatuhan sanksi dari Dewan Keamanan PBB kepada negara yang melakukan pelanggaran hukum internasional. ${ }^{32}$

\section{Ketaatan Terhadap Hukum Per- dagangan Internasional: Implemen- tasi Terhadap Prinsip Itikad Baik}

Telah dijelaskan di atas bahwa hukum perdagangan internasional merupakan cabang dari hukum internasional. Keterkaitan antara dua bidang hukum ini membawa konsekuensi bahwa sumber-sumber hukum internasional juga dapat diadopsi sebagai sumber hukum dalam hukum perdagangan internasional. Salah satu sumber hukum yang menonjol di dalam hukum perdagangan internasional ini adalah perjanjian internasional.

Para penganjur aliran hukum alam dalam hukum internasional berpendapat bahwa kebebasan berniaga merupakan salah satu hak alamiah, namun mereka menafsirkannya secara lebih sempit dalam arti bahwa hak ini tunduk pada sejumlah

\footnotetext{
$31 \quad$ Ibid., 39.

32 Jawahir Thontowi, Hukum dan Hubungan Internasional (UII Press 2016) 24.
} 
pengecualian. Dalam praktik ini berarti bahwa kebebasan berniaga dibatasi oleh batas-batas yurisdiksi mutlak suatu negara.

Oleh karena itu hanya ada satu cara untuk mewujudkan hak alamiah ini, yakni dengan mengadakan perjanjian internasional. ${ }^{33}$ Perjanjian internasional dapat didefinisikan sebagai perjanjian atau kata sepakat antara subjek-subjek hukum internasional. ${ }^{34}$ Secara hukum internasional, perjanjian internasional telah diatur di dalam Konvensi Wina 1969 dan Konvensi Wina 1986. Perbedaan di antara kedua konvensi tersebut hanya terletak pada subjek dari yang membuat perjanjian internasional tersebut. Di dalam Konvensi Wina 1969 adalah antar negara, sementara di dalam Konvensi Wina 1986 subjeknya adalah antar negara dan organisasi internasional.

Saat ini, perjanjian internasional merupakan salah satu sumber hukum internasional yang utama, dan memegang peranan penting dalam hubungan internasional, terutama terkait dengan perdagangan internasional. Hal tersebut memiliki alasan yang kuat, karena hampir sebagian besar hasil hubungan antar negara ataupun antar subjek hukum internasional lainnya, dituangkan dalam sebuah instrumen perjanjian internasional. Melalui perjanjian internasional inilah, sebuah hak dan kewajiban yang telah disepakati oleh berbagai subjek hukum internasional tersebut dirumuskan.
Berdasarkan hal tersebutlah maka bukan hal yang berlebihan jika dikatakan bahwa selama masih berlangsungnya hubungan internasi-onal antar negara, terutama dalam bidang perdagangan, maka selama itu pula perjanjian internasional tersebut akan dilahirkan.

Di dalam ruang lingkup perjanjian internasional, terdapat beberapa prinsip fundamental yang diantaranya adalah pertama prinsip free consent dimana para pihak memiliki kebebasan untuk menyatakan kehendaknya. Prinsip kedua adalah prinsip pacta sunt servanda, dimana perjanjian mengikat seperti undang-undang bagi para pihaknya.

Prinsip ini dikatakan fundamental karena asas tersebut melandasi lahirnya perjanjian, termasuk perjanjian internasional dan melandasi dilaksanakannya perjanjian sesuai dengan apa yang diperjanjikan oleh para pihak. Tanpa adanya janji-janji yang telah disepakati, tidak akan lahir perjanjian. Perjanjian harus dilaksanakan oleh para pihak sebagaimana janji-janji yang diberikan oleh para pihak. ${ }^{35}$ Prinsip ketiga adalah prinsip good faith dimana perjanjian harus dilaksanakan dengan itikad baik oleh pihaknya. ${ }^{36}$

Prinsip ketiga tidak terpisahkan dengan prinsip kedua yang artinya bahwa para pihak harus melaksanakan ketentuan perjanjian sesuai dengan isi, jiwa, maksud, dan tujuan perjanjian itu sendiri, menghormati hak-hak dan kewajiban-kewajiban

\footnotetext{
33 Hata, 'Pemberlakuan Hukum Internasional Publik dalam Instrumen dan Praktik World Trade Organization' (2010) 23 (2) Jurnal Wawasan Hukum 132.

34 I Wayan Parthiana, Perjanjian Internasional di dalam Hukum Nasional Indonesia (Yrama Widya 2019) 82.

35 Purwanto (n 23) 155.

36 Cindawati, 'Prinsip Good Faith (Itikad Baik) Dalam Hukum Kontrak Bisnis Internasional' (2014) 26 (2) Jurnal Mimbar Hukum 191.
} 
dari masing-masing pihak maupun pihak ketiga yang mungkin diberikan hak dan atau kewajiban dan tidak melakukan tindakan-tindakan yang dapat menghambat usaha-usaha mencapai maksud dan tujuan perjanjian itu sendiri, baik sebelum berlaku atau ketika para pihak dalam proses penantian akan mulai berlakunya perjanjian atau juga setelah perjanjian berlaku. ${ }^{37}$

Pentingnya prinsip itikad baik ini dikarenakan di dalamnya terdapat kejujuran, keadilan yang keduanya merupakan nilai-nilai yang penting di dalam melakukan kegiatan perdagangan internasional. ${ }^{38}$

Suatu perjanjian perdagangan internasional mengikat berdasarkan kesepakatan para pihak yang membuatnya. Oleh karena itu, sebagaimana halnya perjanjian internasional pada umumnya, perjanjian perdagangan internasional pun hanya akan mengikat suatu negara apabila negara tersebut sepakat untuk menandatangani atau meratifikasinya. Ketika suatu negara telah meratifikasinya, negara tersebut berkewajiban untuk mengundangkan-nya ke dalam aturan hukum nasionalnya. Perjanjian internasional yang telah diratifikasi tersebut kemudian menjadi bagian dari hukum nasional negara tersebut. ${ }^{39}$

Ketaatan terhadap hukum internasional itu dengan demikian berjalan tanpa adanya paksaan dari pihak tertentu terhadap negara yang mene- rima perjanjian internasional itu, karena penandatanganan tersebut mempunyai arti adanya kemauan dari negara yang bersangkutan untuk tunduk kepada norma internasional yang sudah disepakati di dalam perjanjian internasional. 40

Kegagalan mentaati perjanjian internasional akan melahirkan pertanggungjawaban internasional dan negara tidak dapat berlindung dibalik hukum nasionalnya untuk menjustifikasi kegagalan ini. Dalam hal ini, suatu negara justru harus memastikan bahwa pentaatan perjanjian ini mendapat justifikasi dari hukum nasionalnya. Globalisasi saat ini cenderung mensyaratkan adanya kepastian bahwa setiap hukum nasional negara pihak mentaati perjanjian internasional sehingga dan untuk itu hukum internasional telah mulai mengembangkan suatu meka-nisme pentaatan perjanjian. 41

Di dalam perjanjian perdagangan internasional inilah akan terlihat dan diuji mengenai ketaatan para pihak di dalam menjalankan isi perjanjian perdagangan internasional tersebut. Hadirnya prinsip itikad baik di dalam ruang lingkup perjanjian perdagangan internasional adalah sebagai ketegasan hukum untuk menumbuhkan keadilan yang substantif sehingga tercapai suatu solusi yang adil bagi

\footnotetext{
$37 \quad$ Sefriani (n 4) 84.

38 Andrew D Mitchell, 'Good Faith in WTO Dispute Settlement '(2006) 7 Melbourne Journal of International Law 1.

$39 \quad$ Adolf (n 5) 78.

40 Ratno Lukito, 'Segitiga Hukum Internasional, Municipal dan Islam: Memahami Kompetisi, Interaksi dan Resolusi Hukum di Malaysia' (2015) 49 (1) Asy-Syir'ah Jurnal Ilmu Syar'i dan Hukum 161.

41 Damos Dumoli Agusman, 'Indonesia dan Hukum Internasional: Dinamika Posisi Indonesia Terhadap Hukum Internasional '(2014) 15 (1) Jurnal Opinio Juris 39.
} 
kedua belah pihak yang telah bersepakat. 42

Dengan adanya prinsip itikad baik inilah maka akan dapat memberikan kewajiban kepada suatu negara ketika telah terikat kepada perjanjian perdagangan internasional untuk selalu taat terhadap klausul yang mengatur tersebut. Asas itikad baik ini merupakan prinsip pendukung dan penguat dari asas pacta sunt servanda agar sebuah perjanjian perdagangan internasional dapat dilakukan dan peraturan yang mengikat perjanjian itu juga ditaati oleh negara yang mengikatkan diri terhadap perjanjian tersebut. Kekuatan hukum dalam mengikatnya suatu perjanjian perdagangan internasional tidak dapat ditegakkan terhadap suatu negara jika tidak ada itikad baik untuk melaksanakan perjanjian tersebut, oleh karena itu asas good faith mejadi sangat penting dalam menjalankan perjanjian yang telah disepakati, termasuk dalam perdagangan internasional.

Oleh karena itu, penting bagi kedua negara yang melakukan perdagangan internasional untuk samasama menerapkan itikad baik sehingga potensi untuk terjadinya sengketa akan semakin terminimalisir. 43

\section{Kepentingan Negara Sebagai Alasan Ketaatan Terhadap Hukum Perdagangan Internasional}

Untuk menumbuhkan ketaatan negara pada hukum internasional, Chayes memberikan dua alternatif solusi. Alternatif pertama melalui enforcement mechanism yang mene- rapkan banyak sanksi seperti sanksi ekonomi, sanksi keanggotaan sampai ke sanksi unilateral. Sebagai contoh adalah sanksi yang dikenakan oleh WTO terhadap Indonesia dalam kasus Mobil Nasional (Mobil Timor) setelah melalui proses pemeriksaan perkaranya yang memakan waktu cukup lama.

Alternatif kedua yang ditawarkan Chayes adalah management model, dimana ketaatan tidak dipacu oleh berbagai kekerasan atau sanksi tetapi melalui model kerjasama dalam ketaatan, yaitu melalui proses interaksi dalam justification, discourse and persuasion. Kedaulatan tidak lagi bisa ditafsirkan bebas dari intervensi eksternal, tetapi kebebasan untuk melakukan hubungan internasional sebagai anggota masyarakat internasional. atau otonomi pemerintahan. Dengan demikian kedaulat-an yang baru (the new sovereignty) tidak hanya terdiri dari kontrol wilayah atau otonomi pemerintah tetapi juga pengakuan status sebagai anggota masyarakat bangsa-bangsa. Ketaatan pada hukum internasional tidak lagi semata karena takut akan sanksi tetapi lebih pada kekhawatiran pengurangan status melalui hilangnya reputasi sebagai anggota masyarakat bangsa-bangsa yang baik. ${ }^{44}$

Di atas juga telah dijelaskan bahwa salah satu upaya dari negaranegara di dalam mengefektifkan hukum internasional adalah memasukkan klausula penyelesaian sengketa dalam perjanjian interna-sional. Jika ditarik ke dalam dunia hukum

\footnotetext{
42 Viktorija Budreckiene, 'Good Faith And Fair Dealing In The Commercial Contract Law' (2014) (2) Social Transformations in Contemporary Society 27.

43 Pedro Barasnevicius Quagliato, 'The Duty to Negotiate in Good Faith' (2008) 50 (5) International Journal of Law and Management 216.

44 Harold Hongju Koh, 'Why Do Nations Obey International Law?' (1997) 106 The Yale Law Journal 261.
} 
perdagangan internasional, maka dapat dilihat dari penyelesaian sengketa dalam GATT/WTO. Kekuatan penegakan dan pelaksanaan putusan GATT sendiri didasarkan pada dua hal. Pertama adalah komitmen hukum dari negara-negara anggotanya. Negara-negara anggota GATT dalam menghadapi tuntutan-tuntutan atau sengketa-sengketa dagang dalam GATT lebih menitikberatkan pada rasa hormat dan kepentingannya terhadap GATT. Tindakan negara-negara anggota GATT yang selama ini berdasar pada rasa hormat dan kepentingan, telah menciptakan suatu iklim hukum dimana para anggota GATT melihat adanya kepentingan timbal balik dengan negara lainnya untuk menghormati kewajiban-kewajiban hukum mereka dalam GATT. Kedua adalah GATT mem-berikan hak untuk melaksanakan retaliasi kepada negara yang dirugikan sebagai akibat dari tindakan-tindakan negara lain yang melanggar hukum. Dalam hal ini, negara tersebut diberi hak untuk menerapkan rintangan-rintangan perdagangan baru terhadap produkproduk impor dari negara-negara yang melanggar hukum. ${ }^{45}$

Motivasi dari negara untuk taat kepada hukum internasional, termasuk hukum perdagangan internasional, dikarenakan keyakinan bahwa ketaatan akan menguntungkan kepentingan subjek itu sendiri. Kalkulasi untuk kepentingan sendiri merupakan pondasi tindakan mayoritas masyarakat. Aturan hukum yang dipatuhi oleh individu adalah hasil kalkulasi keuntungan ketaatan versus ketidaktaatan. Meskipun meyakini keuntungan akan diperoleh melalui kerja- sama institusi tetapi kepentingan sendiri tetaplah juga diutamakan.

Dapat disimpulkan bahwa ketaatan negara terhadap hukum internasional terjadi bilamana keuntungan yang akan diperoleh lebih besar daripada biaya yang harus ditanggungnya. Motivasi selanjutnya adalah ketaatan dilandasi keyakinan, penerimaan akan legitimasi normatif dari suatu aturan hukum interna-sional. Negara mentaati aturan hukum internasional bukan karena takut akan sanksi ataupun hitungan untung rugi tetapi benar-benar atas dasar keyakinan negara itu sendiri bahwa aturan itu menimbulkan kewajiban yang harus ditaatinya. Ketaatan menjadi kebiasaan hidup dan ketidaktaatan menimbulkan biaya-biaya tersendiri. ${ }^{46}$

Pada akhirnya, dari berbagai motivasi yang melatarbelakangi suatu negara untuk taat kepada baik hukum internasional dan hukum perdagangan internasional bisa saling mempengaruhi antara satu alasan dengan alasan lainnya.

Jadi pertanyaan mengapa negara taat pada hukum internasional bisa dilandasi oleh masing-masing motivasi di atas ataupun campuran antara motivasi yang satu dengan yang lain. Oleh karena itu, dalam konteks hukum internasional, secara lebih spesifik dibutuhkan penegakannya sebagai upaya untuk menertibkan subjek-subjek hukumnya, yang dalam hal ini adalah negara sebagai bagian dari masyarakat internasional. Kehadiran serta pengaruh dari hukum internasional merupakan hal yang patut untuk diupayakan kehadirannya oleh masyarakat internasional.

\footnotetext{
45 Huala Adolf, Hukum Penyelesaian Sengketa Internasional, (Sinar Grafika 2014) 136.

$46 \quad$ Sefriani (n 26) 424.
} 
Ketaatan suatu negara terhadap hukum internasional, terkhusus hukum perdagangan internasional, bukan diukur dengan penegakan kepatuhan secara kaku dan status berdasarkan kaidah-kaidah normatif yang dikawal oleh para penegak hukum. Keberlakuan hukum internasional harus dilihat dan diukur dari perilaku masyarakat internasi-onal yang taat akan hukum internasional.

Negara selaku makhluk sosial selalu membutuhkan interaksi satu dengan yang lain untuk memenuhi kebutuhannya. Betapapun majunya suatu negara tidak akan dapat hidup sendiri. Saling membutuhkan antara bangsa-bangsa diberbagai lapangan kehidupan yang mengakibatkan timbulnya hubungan yang tetap dan terus menerus antara bangsa-bangsa, mengakibatkan pula timbulnya kepentingan untuk memelihara dan mengatur hubungan demikian.

Dalam berinteraksi tersebut suatu negara membutuhkan aturan hukum untuk memberi kepastian hukum pada apa yang mereka lakukan. Harus diakui bahwa disamping faktor kebutuhan, memang ada juga faktor lain seperti kekhawatiran akan kehilangan keuntungan atau fasilitas-fasilitas dari negara lain juga kekhawatiran dikucilkan dari pergaulan internasional yang memberi kontribusi ketaatan masyarakat internasional pada hukum internasional. Namun demikian semuanya itu mengalahkan ketaatan karena faktor kebutuhan bersama akan adanya aturan hukum yang diharapkan bisa memberikan rasa aman, ketertiban, keadilan, dan kepastian hukum. ${ }^{47}$

Apabila dikaitkan dalam ranah perdagangan, dalam rangka menun- jang pertumbuhan ekonomi suatu negara, maka diperlukan adanya pengaturan perdagangan yang baik, sehingga dapat memelihara kemantapan dan kestabilan perekonomian suatu negara. Hal inilah yang semakin menunjukkan bahwa betapa pentingnya pengaturan perdagangan internasional ini untuk dipatuhi oleh negaranegara. Perilaku kepatuhan negara terhadap hukum perdagangan internasional, pasti akan berpengaruh terhadap siklus atau jalannya suatu perdagangan inter-nasional.

\section{PENUTUP}

Hukum internasional memiliki perbedaan dengan hukum nasional, dimana hukum internasional tidak memiliki badan yang dapat memaksakan penerapan dari hukum internasional itu sendiri. Hal tersebut telah membuat banyak kalangan mengatakan bahwa hukum internasional merupakan hukum yang lemah bahkan hukum internasional bukanlah sebuah hukum. Pandangan tersebut dapat ditepis apabila masyarakat internasional merasakan, menerima, dan menaati suatu kaidah hukum, disebabkan karena memang sesuai dengan kesadaran hukum dan rasa keadilan dari masyarakat, terlepas dari ada atau tidak adanya lembaga ataupun aparat penegak hukumnya, maka kaidah tersebut sudah dapat dipandang sebagai kaidah hukum internasional. Di sinilah arti penting keberadaan hukum perdagangan internasional sebagai bagian dari hukum internasional, dimana hukum perdagangan internasional memegang peranan penting dalam mengatur hubungan perdagangan internasional 
yang ada dalam masyarakat internasional untuk mencapai tujuan yang diinginkan.

Berbagai upaya telah dilakukan oleh masyarakat internasional dalam pengefektifan hukum internasional khususnya hukum perdagangan internasional. Motivasi dari masya-rakat internasional untuk taat kepada hukum perdagangan internasional, dikarenakan keyakinan bahwa ketaatan akan menguntungkan kepentingan subjek itu sendiri. Alasan moral, maupun hukum dapat disatukan menjadi sebuah konsep ketaatan. Kewajiban moral aktor dari pemimpin negara untuk mematuhi norma hukum perdagangan interna-sional menjadi kewajiban hukum domestik yang mengikat secara internal mutlak dilakukan ketika sudah terjadi kesepakatan dengan negara lain.

Selain itu juga terdapat prinsip yang fundamental dalam ruang lingkup perjanjian internasional yang merupakan sumber hukum dari hukum perdagangan internasional, yakni prinsip itikad baik. Adanya prinsip itikad baik inilah maka akan dapat memberikan kewajiban kepada suatu negara ketika telah terikat kepada perjanjian perdagangan internasional untuk selalu taat terhadap klausul yang mengatur tersebut.

\section{DAFTAR BACAAN}

\section{Buku}

Adolf H, Hukum Perdagangan Internasional (RajaGrafindo Persada 2006).

Sengketa Internasional (Sinar
Grafika 2014).

Dixon M, Textbook on International Law (Blackstone Press 1990).
Greig D. W, International Law London (Butterworth 1976).

Guzman A. T, How International Law Works A Rational Choice Theory (Oxford University Press 2008).

Juwana H, Hukum Internasional dalam Perspektif Indonesia sebagai Negara Berkembang (Yarsif Watampone 2010).

\section{Memaksimalkan Peran} Politik Luar Negeri Bebas Aktif: Perspektif Hukum Internasional" dalam Idris, et.al. Peran Hukum Dalam Pembangunan Indonesia Kenyataan, Harapan, dan Tantangan (Rosda Rosdakarya 2013).

Kusumaatmadja M. dan Etty R. Agoes, Pengantar Hukum Internasional (Alumni 2003).

Mauna B, Hukum Internasional Pengetrian Peranan dan Fungsi dalam Era Dinamika Global (Alumni 2013).

Parthiana I W, Pengantar Hukum Internasional (Mandar Maju 2003).

------------, Perjanjian Internasional di dalam Hukum Nasional Indonesia (Yrama Widya, 2019).

Sefriani, Peran Hukum Internasional Dalam Hubungan Internasional Kontemporer (RajaGrafiondo Persada 2016).

Thontowi J, Hukum dan Hubungan Internasional (UII Press 2016).

Twinning W, Globalisation and Legal Theory (Butterworths 2000).

\section{Artikel Jurnal}

Agusman DD, 'Indonesia dan Hukum Internasional: Dinamika Posisi Indonesia Terhadap Hukum 
Internasional' (2014) 15

Jurnal Opinio Juris.

Anggraeni D, 'Pencegahan Praktik Dumping Dalam 'Asean China Free Trade Area' Berkaitan Dengan Peraturan Pemerintah Nomor 34 Tahun 2011' (2017) 5 (1) Jurnal Cita Hukum.

Ariadno MK, 'Kedudukan Hukum Internasional dalam Sistem Hukum Nasional '(2008) 5 (3), Indonesian Journal of International Law.

Budreckiene V, 'Good Faith And Fair Dealing In The Commercial Contract Law', (2014) (2) Social Transformations in Contemporary Society'.

Cindawati, 'Prinsip Good Faith (Itikad Baik) Dalam Hukum Kontrak Bisnis Internasional', (2014) 26 (2) Jurnal Mimbar Hukum.

Darajati MR, 'Pemberlakuan Ketentuan Regulatory Coherence dalam Trans Pacific Partnerhip Agreement Bagi Negara Pihak dalam Perspektif Indonesia' (2019) 4 (2) University of Bengkulu Law Journal.

Hata, 'Pemberlakuan Hukum Internasional Publik Dalam Instrumen Dan Praktik World Trade Organization '(2010) 23 (2) Jurnal Wawasan Hukum.

Jamilus, 'Analisis Fungsi Dan Manfaat WTO Bagi Negara Berkembang (Khususnya Indonesia) '(2017) 11 (2) Jurnal Ilmiah Kebijakan Hukum.

Koh HH, 'Why Do Nations Obey International Law? '(1997) 106 The Yale Law Journal.

Latifah E, 'Eksistensi Prinsip-prinsip Keadilan dalam Sistem Hukum
Perdagangan Internasional ' (2015) 2 (1) Padjadjaran Jurnal Ilmu Hukum.

Lukito R, 'Segitiga Hukum Internasional, Municipal dan Islam: Memahami Kompetisi, Interaksi dan Resolusi Hukum di Malaysia '(2015) 49 (1) AsySyir'ah Jurnal Ilmu Syar'i dan Hukum.

Mandala S, 'Harmonisasi Hukum Perdagangan Internasional: Sejarah, Latar Belakang Dan Model Pendekatannya '(2016) 1 (1) Jurnal Bina Mulia Hukum.

Mitchell AD, 'Good Faith In WTO Dispute Settlement '(2006) 7 Melbourne Journal of International Law.

Prakasa SUW, 'Perdagangan Internasional Dan Ham: Relasinya Dengan Suistainable Development '(2018) 9 (1) Jurnal Hukum Novelty.

Purwanto H, 'Keberadaan Asas Pacta Sunt Servanda Dalam Perjanjian Internasional '(2009) $21 \quad$ (1) Mimbar Hukum.

Quagliato PB, 'The Duty to Negotiate in Good Faith '(2008) $50 \quad$ (5) International Journal of Law and Management.

Rajagukguk E, 'Menjaga Persatuan Bangsa, Memulihkan Ekonomi, dan Memperluas Kesejahteraan Sosial '(2003) 22 (5) Jurnal Hukum Bisnis.

Riyanto S, 'Kedaulatan Negara dalam Kerangka Hukum Internasional Kontemporer '(2012) 1 (3) Yustisia.

Sefriani, 'Ketaatan Masyarakat Internasional terhadap Hukum Internasional dalam Perspektif 
Filsafat Hukum' (2011) 18 (3) Jurnal Hukum Ius Quia Iustum.

Suherman AM, 'Perdagangan Bebas (Free Trade Dalam Perspektif Keadilan Internasional '(2008) 5 (2) Indonesian Journal of International Law.

Wijaya E, Nopiandri K, dan Habiburrokhman, 'Dinamika Upaya Melakukan Sinergi Antara Hukum Perdagangan Internasional dan Hukum Lingkungan '(2017) 6 (3) Jurnal Hukum dan Peradilan.

\section{Seminar/Konferensi}

Juwana H, 'Masyarakat Ekonomi ASEAN dan Tantangannya bagi Indonesia: Dalam Perspektif Hukum Perdagangan Internasional' (Dies Natalis Universitas Indonesia, Depok, Februari 2016). 